\title{
Sisters before Misters: The Triumph of Feminism over Patriarchy in Toni Morrison's Love
}

\author{
Milica Milovanović
}

\begin{abstract}
Rare are the authors that can strike the right note which will create a rhapsody comprised of a timeless topic, pure emotion and a meaningful message, especially in a 200-page-long novel. But that is precisely what Toni Morrison did in Love, her eighth novel, which will be used to prove that feminism can rule out the patriarchal oppression. The broken bond of sisterhood between the protagonists, Heed and Christine, caused by the influence of a ruthless patriarch Bill Cosey, has been mended with the restored power of a child's first love, stronger and purer even than the parental one. The fact that Heed dies in the end is a symbol of the price that needs to be paid for a bigger cause, the triumph of feminism, but it is not something that strong women like Heed and Christine are not able to come to terms with.
\end{abstract}

Index Terms - Feminism, Love, Patriarchy, Sisterhood

\section{INTRODUCTION}

Mar Gallego claims that Toni Morrison tackles many key issues in her fiction: the empty category of race or the uselessness of racial boundaries, the rewriting of history from an African-American standpoint, the importance of the survival of the community, the definition of black womanhood and so on [2]. However, the motif of broken sisterhood also plays a significant role, so Sy rightly believes that Morrison did not create an example of a successful sisterhood in any of her novels, but that she uses it to point out the dangers of patriarchy, although she eagerly supports female friendships [4]. The novel Love is probably the one that personifies that claim the most of all the novels from the authoress' opus. Tsai claims that the novel is also marked with the typical Morrisonian style-multiple perspectives, fragmentary or circular narrations that imply a traumatic past and a ghostly voice or presence that haunts the characters, their house or community [6]. I believe that the fact the novel is told through a variety of voices and a multitude of flashbacks contributes to its fullness and influences the reader even more, given the fact that he only gradually becomes aware of how changed the nature of Christine and Heed's relationship actually is.

${ }^{1}$ Paper submitted for review August 3, 2017.

Milica Milovanović, Ph.D. Student, Faculty of Philology, University of Belgrade, Serbia

\section{II. (FR)ENEMIES-CHRISTINE AND HEED}

The cause of the abovementioned change, according to Sy lies in the fact that both Christine and Heed suffer from patriarchal oppression executed by Bill Cosey which makes them alienated from each other and disables them from forming a meaningful relationship [4]. Actually, the main reason for the rift between the two is Bill Cosey's marriage with Christine's eight months younger friend, Heed, due to his sexual preferences. That turned the once inseparable friends into bitter individuals forced to share the same living space-one of them is there because she has nowhere else to go while the other one behaves in such a way since, suffering from arthritis, she needs help. "With very few words they came to an agreement of sorts because May was hopeless, the place filthy, Heed's arthritis was disabling her hands and because nobody in town could stand them" [5, p. 86]. Even in the very beginning of the novel it is visible that both women use every opportunity to do wrong to the other one. This is especially true when Christine makes a dish she is sure will remain untouched because "what she knows is I don't eat shellfish" [5, p. 28]. The seed of hostility between the two was planted as soon as the wedding was over and May told Christine that she should sleep in the smaller bedroom on the second floor because "it was for her own protection. There were things she shouldn't see or hear ir know about" [5, p. 95]. The reason she did that was the fact that the atmosphere in the house became so unsuitable that Christine could "soak it up faster than a fruitcake soaks up rum" [5, p. 139]. The belief that May is the one to blame for the rift between the girls is supported by L's statement that "nothing she aimed for had gone her way-except for the hatchet she threw between Heed and Christine when they were little girls. That stuck. Cleaved the ground they stood on" [5, p. 141]. It is possible that May took all those precautions to protect Christine from negative influences, but a conclusion that she carried it all out, at least partially, for personal pleasure and paying homage to justice, since Cosey betrayed her seven-year long dedication to him and the hotel by marrying Heed, also imposes itself on the reader.

Vida Gibbons, the woman who worked at Cosey's resort, reveals that the animosity between the two women reached its peak on the day of Cosey's funeral when they fought over his coffin and Christine closed her switchblade; Heed picked up her ridiculous hat and moved to the other side of the grave. Their faces, as different as honey from soot, were identical at that moment because "hate does that. Burns off everything but 
itself, so whatever your grievance is, your face looks just like your enemy's" [5, p. 34]. The real cause of Christine's anger was that the locals treated Heed as if she was the only one to suffer a loss while she and May were nothing more than undesired visitors. Heed's false tears also bothered her, as well as the over-emphasized shudder of her shoulders (which makes the sincerity of her feelings seem questionable) as well as the fact that they prevented her from putting diamond rings on Cosey's hands. The cook, $\mathrm{L}$ was the only one who could put an end to possible incidents, "forcing them to bite back their tongues, which by all reports they were still doing while waiting for the other one to die" [5, p. 37]. Since the moment Christine came back home their fights were mostly verbal "but there were also bruising fights with hands, feet, teeth and soaring objects (...) Once-perhaps twice-a year they punched, grabbed hair, wrestled, bit, slapped (...) That was as much rite as fight [5, p. 71]. According to Morrison Christine should be the one to win every fight due to her size, but Heed more than compensated for her lack of strength with her speed and cunning which tired her enemy. The truce finally happened when their age and the realisation that neither of them could leave made them understand that fights only made them more dependable on each other. How far these two were ready to go in order to take over the house is perhaps best described by the fact that Heed set Christine's bed on fire in order to keep her away. May and Christine were horrified by such behaviour. "She's going to kill us", May hissed and when Cosey said the bed was empty, she retorted "Tonight it was, what about tomorrow" [5, p. 134]. In the end it was Christine who had to leave the house although she wasn't the one who caused the incident because Cosey "didn't marry Christine. "I [He] married Heed" [5, p. 135]. The fact that Christine had to leave their nest made their relationship even worse. How shocking and sudden was the change is best described by Christine's words: "One day we built castles on the beach; next day he sat her in his lap. One day we were playing house under a quilt; next day she slept in his bed. One day we played jacks; the next she was fucking my grandfather. One day this house was mine; next day she owned it" [5, p. 133].

After that, all the subtle feelings were replaced by hatred and envy. Still, I believe that only love that you once felt for someone could cause negative feelings of the same intensity, which is somehow illustrated by L's words at the end of the novel, when the full scale of those feelings had already been revealed: "If such children find each other before they know their own sex, or which one of them is starving, which well fed; before they know color from no color, kin from stranger, then they have found a mix of surrender and mutiny they can never live without. Heed and Christine found such a one" [5, p. 199]. She calls it a child's first chosen love which makes even the parental one secondary. The previous nature of their relationship is hard to imagine due to the fact that it's not exposed until the very end of the novel when both women find themselves in the attic "abandoned seven miles from humanity with nobody knowing they are there or caring even if they do know? No one is praying for them and they have never prayed for themselves" [5, p. 184]. Both of them contributed to their current position: "Who started it all by hiring a thief and who made it necessary by consulting a lawyer?" [5, p. 184]. The friends who even had their secret language, idagay which, according to Morrison, was for intimacy gossip, telling jokes on grown-ups and used only once to draw friendly blood-those friends reached a point when they could talk only with their fists, or else, did not talk at all. Despite all their intimacy "Even in idagay they had never been able to share a certain twin shame" [5, p. 190]. It was the situation when Cosey saw Heed on the beach for the first time. Heed plans on telling her what happened, but when she finds her "She looks sick, disgusted, and doesn't meet Heed's eyes. Heed can't speak, can't tell her friend what happened. She knows she has spoiled it all" [5, p. 191]. The first of many lies she uttered was that she could not find the jacks they needed for the card game which Christine had sent her to bring at the moment she met her grandfather. She lied because she thought that Christine vomited since she had just witnessed what happened. What she did not know, however, was that Christine had an equally shameful experience with her grandfather when she caught him onaniating in her room.

The next unpleasant moment in their interaction occurred when Heed came back from her honeymoon with Cosey and she could not wait to tell Christine all about it. Christine greeted her coldly, however, so she kept the stories for herself and then offered Christine to wear her wedding ring, unaware that such a gesture would cause a strong reaction among all the women and make Christine cry and call her a slave. The consequences of these experiences were so traumatic for both of the girls that years had gone by before they mustered up the courage to talk about that when it had already been too late. They realised that they thought him up, that he thought himself up, actually, and that they both helped him, that he was everywhere and nowhere at the same time and that only the devil himself could make him that way. What affected the two of them the most was the fact that they lost each other in the process" - He took all my childhood away from me, girl. -He took all of you away from me" [5, p. 194]. It is important to say that besides the secret language they had the word Celestial as well, which was "their most private code" [5, p. 188]. According to Morrison, that word was used to denote every risky, particularly brave move and even the castle they played in was named after it, Celestial Palace. What made them even closer to each other at that moment was the fact that their mothers treated them in a similar way, i.e. they did not care much about them. Heed tried to console Christine by telling her she was not sold the way Heed was, but Christine said to her that her mother gave her away to the Maple Valley boarding school because Cosey demanded it. Christine also reveals that the only thing her mother liked about her was that she hated Heed. The bond between the two was so strong that "neither ever intended to abandon the other, yet both in fact do so" $[1, \mathrm{p}$. 34]. Fulton believes this was caused by the outside influences and that it was necessary for them to understand who controlled their behaviour so they could reconciliate. Christine's room, the setting of the reconciliation, according to Fulton, makes the two women "understand the mistake they have made in abandoning their friendship and relying on their patriarchally dictated heterosexual identities in their search for self-actualization" [1, p. 37]. The same author also believes that during the final scene of the novel their voices become 
almost inseparable because they suffered similar betrayal and regrets. Fulton finishes off by saying that individual healing is not possible but that they can reach it together and even happiness beyond that. Because of that epiphany, Christine came all the way from a girl smiling coldly at the camera during Heed's wedding while holding a rose (which was her idea of a silent protest about their marriage), to a grown woman who realises that she lost her most precious friend because of the selfishness of other people. Still, the fact that they succeeded in rekindling their relationship, even if for just a short period and at a price of one life, depicts the triumph of feminism over patriarchy in its fullest, supported by Christine's "I love you. I really do" [5, p. 194] at the moment of Heed's death.

\section{HEED'S BREAK-UP WITH PATRIARCHY}

Heed ended up being the best positioned one of all the protagonists although no one actually expected that- the girl who had neither a nightgown nor a bathing suit, who did not know that different kinds of food were served on separate plates, who slept on the floor and bathed in murky water after her sisters-fought them all and won. According to Morrison, May was buried in the ground and Christine sat penniless in the kitchen while L haunted people in Up Beach. Sy claims that Heed decided to stay with the man old enough to be her grandfather because she had never made a decision in her life and that this act also shows that she was not mature although she was older [4]. In my opinion, however, she did protest against patriarchy on one occasion, and her husband who personified it as well, by taking a step away from what she used to be like. The proof for that is her affair with a man named Knox Sinclair who came to the resort to take his dead brother's body. He was the first one who made Christine realise what it looked like when you were loved for your own being and not one's sexual preferences as in Cosey's case "suddenly aware of the difference between being needed and being obliged" [5, $\mathrm{p}$. $171]$.

Although he promised he would come back in six weeks' time, he never showed up again. She phoned him over and over again up to the point when his mother asked her not to do that again. She soon stopped mourning the loss of a lover; however, since she found out she was pregnant, after fifteen years of questioning her own fertility. "She would trade a father for a child any day" [5, p. 173].

She started bleeding, but the doctor assured her everything was running smoothly and she did not doubt that because she had all the symptoms of a pregnancy. May was the one who made her face reality by telling her "Wake up girl! Your oven is cold" [5, p. 174]. The very fact that Heed gathered the courage to cheat on her husband shows her readiness to break up with patriarchal conventions. She paid him back in the same coin for his numerous infidelities. Besides, her six-day-long affair with Knox Sinclair was her first independent act, given the fact that before and during her marriage with Cosey she always did what was expected from her, or what Cosey wanted her to do. With this act she established herself as a woman because it was the first time she felt real emotions, simultaneously making other people regard her as something more than Cosey's child bride. She came a long way, from clay moulded in someone else's hands to an exquisite upright statue, standing on her own.
Garcia Carmen Rosette believes that the state of the hotel actually depicts the position of patriarchy in relation to the feminist movement because "the winds of feminist change have taken their toll (...) and a washed up resort mirrors a washed up patriarch" [3, p. 27]. It is further explained that the hotel, as well as all the property Cosey had became Heed and Christine's, the new generation of women who foreshadow patriarchy's demise. Rosette claims that Morrison prepares the reader for fuller understanding of the problems pointed out in the opening chapter of the novel by ingeniously interweaving the motifs of female sexuality, male dominance, female subordinacy and male hostility into a composition which emphasises the gender polarity of these concepts.

According to Rosette, the novel Love can be read as a testament to feminist success in its portrayal of the waning influence-if not actual demise-of the patriarch over the course of the last half of the twentieth century. The same author further claims that Morrison creates a story of feminist success over the patriarchal oppression with the help of the narrative voice, setting and characterisation to depict a literal and allegorical shift (of the patriarch) from perceived centre to actual margin, from the top of the heap to the bottom of the pile, from health and wealth to ignominious death, indicating a similar shift from patriarchal dominance to patriarchal irrelevance in American society, but she still leaves it up to the reader to decide on the nature of the post-patriarchal narrative.

\section{CONCLUSION}

The development of feminism as a movement for ensuring women's rights occurred in several different stages. Especially turbulent was the second half of the twentieth century which brought up a substantial shift in its functioning. The fact that the society still suffered from male domination, i. e. patriarchal oppression was what slowed down the further advancement of the feminist movement. One of the most striking examples of feminist success over patriarchal conventions in the field of literature most certainly is the relationship that the protagonists of Toni Morrison's novel Love, Christine and Heed, have. What started as an ideal depiction of the motif of broken sisterhood returned to its previous, most sincere form until the end of the novel-the love that Heed and Christine felt for each other when they were children, which is more important even than the parental one. It is true that the real development of the situation is not even hinted at until the very end of the novel and that the price of it was perhaps a bit too high (one person's life). However, the final acts of the novel imply that the roles of feminism and patriarchy as two opposing currents will differ significantly in the future. The fact that Heed dies could be a message that such a goal cannot be achieved without a certain price, but that is something that women as strong as Christine and Heed are able to bear.

\section{REFERENCES}

[1] Fulton, Lynn Katharine. Female Sexuality in Toni Morrison's Love. Iowa State University, 2009.

[2] Gallego, Mar. "Love and the survival of the black community". The Cambridge Companion to Toni Morrison edited by Justine Tally. Cambridge University Press. Cambridge, 2007, 92-100. 
[3] Garcia, Carmen Rosette. Love in the Time of Feminism: Patriarchy, Sexuality, and Masculinity in Toni Morrison's 'Love, a Novel'. California State University-San Marcos, 2015.

[4] Kadidia, Sy. Women's relationships: Female Friendships in Toni Morrison's Sula and Love, Mariamaba's So Long a Letter and Sefi Atta's Everything Good Will Come. Georgia State University, 2008.

[5] Morrison, Toni. Love Vintage. Penguin Random House UK, 2016.

[6] Tsai Chai-chin. „But the greatest of these is Love: Desire for the Father and Agape in Toni Morrison's Love“. Concentrics: Literary and Cultural Studies. Volume 36, Issue 1, 2010, 217-241.

Milica Milovanovic was born in Bijeljina, Republica Srpska, Bosnia and Herzegovina on 6 March, 1992. She completed her primary and secondary school education as a straight-A student. She earned her BA Degree in English Language and Literature from Slobomir P University in Bijeljina, Republica Srpska, Bosnia and Herzegovina in 2015. She went on to complete her MA Studies of the English Language, Literature and Culture at the Faculty of Philology, University of Belgrade, Serbia in 2016, and is currently a PhD Student at the same institution.

She is also a volunteer for an organisation based in Serbia called The Translator's Heart which translates medical documentation into English for people who seek treatment in foreign countries. The author's research interests include the Anglo-American literature, the American contemporary novel, Translation Studies and the medical register of the English language.

Milica Milovanovic has been awarded Diplomas in recognition of her success as a straight-A student both in primary and secondary school, an award for the student with the highest GPA at her Faculty in 2015, and has also been given a number of scholarships for prospective students. 